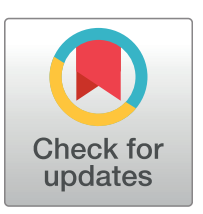

\section{Gopenaccess}

Citation: Liu L, Hou J, Xu Y, Qin L, Liu W, Zhang H, et al. (2020) PD-L1 upregulation by IFN- $\alpha / \gamma^{-}$ mediated Stat1 suppresses anti-HBV T cell response. PLOS ONE 15(7): e0228302. https://doi. org/10.1371/journal.pone.0228302

Editor: Isabelle Chemin, Centre de Recherche en Cancerologie de Lyon, FRANCE

Received: January 9, 2020

Accepted: June 8, 2020

Published: July 6, 2020

Peer Review History: PLOS recognizes the benefits of transparency in the peer review process; therefore, we enable the publication of all of the content of peer review and author responses alongside final, published articles. The editorial history of this article is available here: https://doi.org/10.1371/journal.pone.0228302

Copyright: @ 2020 Liu et al. This is an open access article distributed under the terms of the Creative Commons Attribution License, which permits unrestricted use, distribution, and reproduction in any medium, provided the original author and source are credited.

Data Availability Statement: All relevant data are within the manuscript and its Supporting Information files.

Funding: This work was supported by a grant from the Strategic Priority Research Program of the

RESEARCH ARTICLE

\title{
PD-L1 upregulation by IFN-a/Y-mediated Stat1 suppresses anti-HBV T cell response
}

\author{
LanLan Liu ${ }^{1,20}$, Junwei Hou ${ }^{1,30}$, Yuxiu Xu $u^{1,3}$, Lijuan Qin ${ }^{1,3}$, Weiwei Liu ${ }^{1,3}$, Han Zhang ${ }^{1,3}$, \\ Yang Li ${ }^{1,3}$, Mi Chen ${ }^{1,3}$, Mengmeng Deng ${ }^{1,3}$, Bao Zhao ${ }^{1,3}$, Jun $\mathrm{Hu}^{1,3}$, Huaguo Zheng ${ }^{1,3}$, \\ Changfei $\mathrm{Li}^{1,3 *}$, Songdong Meng ${ }^{1,3 *}$
}

1 CAS Key Laboratory of Pathogenic Microbiology and Immunology, Center for Biosafety Mega-Science, Chinese Academy of Sciences (CAS), Institute of Microbiology, Beijing, China, 2 Institutes of Physical Science and Information Technology, Anhui University, Hefei, China, 3 University of Chinese Academy of Sciences, Beijing, China

ه These authors contributed equally to this work.

* mengsd@im.ac.cn (SM); lichangfei2006@163.com (CL)

\section{Abstract}

Programmed death ligand 1 (PD-L1) has been recently shown to be a major obstacle to antiviral immunity by binding to its receptor programmed death 1 (PD-1) on specific IFN-y producing T cells in chronic hepatitis B. Currently, IFN- $\alpha$ is widely used to treat hepatitis B virus (HBV) infection, but its antiviral effect vary greatly and the mechanism is not totally clear. We found that IFN- $\alpha / y$ induced a marked increase of PD-L1 expression in hepatocytes. Signal and activators of transcription (Stat1) was then identified as a major transcription factor involved in IFN- $\alpha / \mathrm{Y}$-mediated PD-L1 elevation both in vitro and in mice. Blockage of the PDL1/PD-1 interaction by a specific $m A b$ greatly enhanced HBV-specific $T$ cell activity by the gp96 adjuvanted therapeutic vaccine, and promoted HBV clearance in HBV transgenic mice. Our results demonstrate the IFN- $\alpha / \mathrm{Y}$-Stat1-PD-L1 axis plays an important role in mediating $T$ cell hyporesponsiveness and inactivating liver-infiltrating $T$ cells in the hepatic microenvironment. These data raise further potential interest in enhancing the anti-HBV efficacy of IFN- $\alpha$ and therapeutic vaccines.

\section{Introduction}

Up to 350 million individuals worldwide are currently chronically infected with hepatitis B virus (HBV). Ultimate $\mathrm{HBV}$ clearance requires the coordination of the potent $\mathrm{T}$ cell immune response and effective humoral immunity. However, HBV-specific T cell response, which plays a vital role in HBV clearance, is severely impaired in chronic hepatitis B (CHB) patients, leading to long-term immune tolerance $[1,2]$. Several mechanisms may contribute to HBVspecific $\mathrm{T}$ cell exhaustion, including upregulation of co-inhibitory molecules such as programmed death 1 (PD-1), T-cell immunoglobulin and mucin domain-containing molecule 3 (TIM-3), T-cell immunoglobulin and ITIM domain (TIGIT), lymphocyte-activation gene 3 (LAG3), immunosuppressive prostaglandin E2 (PGE2) receptors, cytotoxic T-lymphocyte antigen 4 (CTLA-4), and proapoptotic protein Bcl2-interacting mediator (Bim) on HBV- 
Chinese Academy of Sciences (XDB29040000), a grant from One Belt and One Road International Science and Technology Cooperation of Chinese Academy of Sciences (153211KYSB20170001), the Industrial innovation team grant from Foshan Industrial Technology Research Institute, Chinese Academy of Sciences, and grants from the National Natural Science Foundation of China (81761128002, 81621091, 81871297, 81672815, $81471960,81903142)$ to SM and BZ. The authors acknowledge materials support from Beijing Combio Company and Beijing Tiantan Biological Products Company. The funders had no role in study design, data collection and analysis, decision to publish, or preparation of the manuscript.

Competing interests: The authors acknowledge materials support from Beijing Combio Company and Beijing Tiantan Biological Products Company. This does not alter our adherence to PLOS ONE policies on sharing data and materials. specific $\mathrm{CD}^{+} \mathrm{T}$ cells, as well as on $\mathrm{CD} 4+\mathrm{T}$ cells and $\mathrm{NK}$ cells [3-5]. Additionally, regulatory $\mathrm{T}$ cells and suppressive cytokines also contribute to virus-specific $\mathrm{T}$ cell failure [6].

Among the co-expressed inhibitory receptors on $\mathrm{T}$ cells, programmed death ligand 1 (PD-L1) plays a critical role in impaired T cell immune responses. Of note, its ligand PD-L1, a $40 \mathrm{kDa}$ transmembrane protein, is constitutively expressed on liver DCs, Kupffer cells, stellate cells, liver sinusoidal endothelial cells, and hepatocytes. Binding of PD-L1 to PD-1 leads to T cell dysfunction by inhibiting $\mathrm{T}$ cell activation, causing $\mathrm{T}$ cell exhaustion, anergy, and $\mathrm{T}$ cell apoptosis, as well as by inducing Treg differentiation [7-11]. In addition, elevated PD-L1 levels in liver were observed in chronic necroinflammatory liver diseases and autoimmune hepatitis $[12,13]$. These indicate the immune regulatory function of the liver microenvironment that may lead to $\mathrm{T}$ cell exhaustion.

As an first-line treatment option, IFN- $\alpha$-based therapies achieve a sustained off-treatment response and a more likely functional cure, and prevent occurrence of hepatocellular carcinoma in patients with CHB $[14,15]$. Virus-specific IFN- $\gamma$ secreting CD8+ and CD4+ T cells are believed to play a key role on HBV clearance and control [16-18]. However, both type I/II interferons were shown to promote PD-L1 expression in hepatocytes, which may induce T cell apoptosis [19-21]. Therefore, further elucidating the mechanism of hepatic PD-L1 expression induced by IFN- $\alpha / \gamma$ and its role in T cell response will shed light on the underlying mechanism of antiviral $\mathrm{T}$ cell exhaustion and the unique immunological properties of liver.

Here, we aimed to explore the mechanism of PD-L1 upregulation in hepatocytes by IFN- $\alpha$ / $\gamma$ and the potential role of PD-L1 in regulating virus-specific T cell responses in liver. The results could provide valuable insights into the modulation of hepatic PD-L1 expression by type $\mathrm{I} / \mathrm{II}$ interferons, and offer novel therapeutic combination strategies for reversing $\mathrm{T}$ cell immune exhaustion in CHB.

\section{Materials and methods}

\section{Cell lines}

The human hepatic cell line L02 originated from normal human liver tissue immortalized by stable transfection with the human telomerase reverse transcriptase (hTERT) gene [22, 23]. The L02 and Huh7 cell lines were obtained from the Cell Bank of the Chinese Academy of Sciences (Shanghai, China) and maintained in the lab. The L02 and Huh7 cell lines were cultured in Dulbecco's modified Eagle's medium (DMEM) containing 10\% heat-inactivated fetal bovine serum, $1 \mathrm{~g} / \mathrm{L}$ of glucose, $1 \mathrm{mmol} / \mathrm{L}$ of glutamine, $100 \mathrm{U} / \mathrm{mL}$ of penicillin, and $100 \mu \mathrm{g} /$ $\mathrm{mL}$ of streptomycin, and incubated in $5 \% \mathrm{CO} 2$ at $37^{\circ} \mathrm{C}$.

\section{Plasmids, antibodies, and reagents}

The Stat1 expression plasmid pCMV-Stat1, pGL3-PD-L1 promoter-luciferase (PD-L1-wt) and pGL3-PD-L1 promoter-mutant-luciferase (PD-L1-mut) with mutated Stat1 binding site were constructed by our lab. Rabbit Stat1 antibody and phospho-Stat1 monoclonal antibodies were purchased from Cell Signaling Technology (MA, USA). The anti-PD-1 monoclonal antibody $(\mathrm{mAb})$ was kindly provided by Beijing Combio Company (Beijing, China). The PD-L1 monoclonal antibody was obtained from eBioscience (MA, USA). The specific Stat1 inhibitor fludarabine was from Selleck Chemicals (TX, USA). The Dual-Gloß Luciferase Assay System was purchased from Promega Corporation (WI, USA). The human IFN- $\alpha$ and IFN- $\gamma$ proteins, as well as the murine IFN- $\alpha$ protein were purchased from Sino Biological Inc (Beijing, China). The HBs protein was kindly given by Beijing Tiantan Biological Products Company (Beijing, China). The gp96 and HBc proteins were expressed and purified in our lab respectively as described previously $[24,25]$. The recombinant murine IFN- $\gamma$ protein was purchased from 
PeproTech Inc. (NJ, USA). Mouse IFN- $\gamma$ precoated ELISPOT kit was provided by Dakewe Inc. (Shenzhen, China). The HBsAg and HBeAg test kits were purchased from Shanghai Kehua Bio-Engineering Ltd. (Shanghai, China). HBV nucleic acid amplification fluorescent quantitative assay kit and Alanine Transaminase Assay kit were purchased from Beijing Biodee diagnostics Ltd. (Beijing, China). The sequences of PD-L1 promoter and Stat1-specific siRNA are listed in Table 1.

Western blotting, flow cytometry analysis of cell membrane PD-L1 levels, immunohistochemistry (IHC) analysis, and real-time PCR were performed as described previously [26]. The primers used in real-time PCR are indicated in Table 2. Luciferase reporter assays were performed as described previously [27]. Flow cytometry and intracellular cytokine staining of $\mathrm{CD}^{+}$or $\mathrm{CD}^{+}{ }^{+} \mathrm{T}$ cells, IFN- $\gamma$ ELISPOT, serum ALT detection, and virology assessment (serum HBs and $\mathrm{HBe} \mathrm{Ag}$, and HBV DNA copies) were performed as described previously [24].

\section{IFN- $\alpha$ and IFN- $\gamma$ treatment in mice}

Six-week-old male BALB/c mice were purchased from Vital River Laboratories. Six-week-old male BALB/c HBV transgenic mice were purchased from Transgenic Engineering Lab, Infectious Disease Center, Guangzhou, China. Mice were randomly divided into 5 groups ( $\mathrm{n}=5$ / group) and injected with PBS, IFN- $\alpha\left(5 \times 10^{4} \mathrm{U} / \mathrm{kg}\right)$, IFN $-\gamma\left(1.6 \times 10^{4} \mathrm{U} / \mathrm{kg}\right)$, and/or the specific Stat 1 inhibitor fludarabine $(40 \mathrm{mg} / \mathrm{kg}$ ) every 3 days for 5 times, respectively. Three days after the last injection, all the mice were sacrificed, and the mouse livers were fixed in formalin and prepared for IHC analysis.

\section{Combined therapy with anti-PD-1 $\mathrm{mAb}$ and $\mathrm{HBV}$ therapeutic vaccine}

Six-week-old male BALB/c HBV transgenic mice were purchased from Transgenic Engineering Lab, Infectious Disease Center, Guangzhou, China. The HBV transgenic mice were generated with a viral DNA construct, pHBV1.3, containing 1.3 copies of the HBV genome. All transgenic mice were tested positive for serum HBsAg and viral DNA, as well as HBc expression in hepatocytes in their livers. Mice were randomly divided into 4 groups ( $n=5$ /group). Mice were subcutaneously immunized with $\mathrm{HBV}$ therapeutic vaccine $(10 \mu \mathrm{g} \mathrm{HBs}+10 \mu \mathrm{g} \mathrm{HBc}$ $+25 \mu \mathrm{g}$ gp96/mouse) at weeks 1,2, and 4, respectively, and/or intraperitoneally injected with anti-PD-1 mAb (100 $\mu \mathrm{g} /$ mouse) at weeks 1, 2, 3, and 4, respectively. Mice were sacrificed at week 9 for antiviral $\mathrm{T}$ cell analysis and virology assessment.

\section{Statistical analysis}

All data were presented as mean \pm SD, and significance was determined by two-tailed Student's t test unless specified. A $P$ value of less than 0.05 was considered statistically significant. In figures * indicates for $\mathrm{P}<0.05$, ${ }^{* *}$ for $\mathrm{P}<0.01$ and ${ }^{* * *}$ for $\mathrm{P}<0.001$.

\section{Study approval}

Animal studies were approved by the Institute of Microbiology, Chinese Academy of Sciences of Research Ethics Committee (permit number PZIMCAS2011001). All animal experiments were performed in strict accordance with institutional guidelines on the handling of laboratory animals. 
Table 1. This is the sequences of promoter, siRNA.

\begin{tabular}{|c|c|}
\hline Gene & promoter/siRNA \\
\hline PD-L1 promoter & $\begin{array}{l}\text { 5'-TCATAACCAATGCAAGGGCTATCTCAATATTCATT } \\
\text { CATTATGCAGTATTTGAACTGCAGTTGAAATGA } \\
\text { ATAAGAAGGAAAGGCAAAAACGAGAGTCCAAT } \\
\text { TTCTCAATTTAGAAAAAGAGAAAAAAAAGAAAAGG } \\
\text { GAGCACACAGGCACGGTGGCTCAAGCCTGTAATAT } \\
\text { CAGCACTTTGGCGGATCACTTGAGGTCAAGGAGTT } \\
\text { CGAGAAAAGAGAGCACCTAGAAGTTCAGCGCGGAT } \\
\text { AATACTTAAGTAAATTATACACCATCGTCTGTCATC } \\
\text { TTGGGCCCATTCACTAACCCAAAGCTTTCAAAAGGGC } \\
\text { TTTCTTAACCCTCACCTAGAATAGGCTTCCGCAGCCTT } \\
\text { AATCCTTAGGGTGGCAGAATATCAGGGACCCTGAGCAT } \\
\text { TCTTAAAAGATGTAGCTCGGGATGGAAGTTCTTTAA } \\
\text { TGACAAAGCAAATGAAGTTCATTATGTCGAGGAACTT } \\
\text { TGAGGAAGTCACAGAATCCACGATTTAAAAATATATTTC } \\
\text { CTATTATACACCCATACACACACACACACACCTACTTTCT } \\
\text { AGAATAAAAACCAAAGCCATATGGGTCTGCTGCTGACTT } \\
\text { TTTATATGTTGTAGAGTTATATCAAGTTATGTCAAGATG } \\
\text { TTCAGTCACCTTGAAGAGGCTTTTATCAGAAAGGGGGAC } \\
\text { GCCTTTCTGATAAAGGTTAAGGGGTAACCTTAAGCTCTT } \\
\text { ACCCCTCTGAAGGTAAAATCAAGGTGCGTTCAGATGTTG } \\
\text { GCTTGTTGTAAATTCTTTTTTATTAATAACATACTAAA } \\
\text { TGTGGATTTCTTTAATCTTCGAAACTCTTCCCGGTGAAA } \\
\text { ATCTCATTTACAAGAAAACTGGACTGACATGTTTCACTTTC } \\
\text { TGTTTCATTTCTATACACAGCTTTATTCCTAGGACACCAAC } \\
\text { ACTAGATACCTAAACTGAAAGCTTCCGCCGATTCACCGAA } \\
\text { GGTCAGGAAAGTCCAACGCCCGGCAAACTGGATTTGCTGC } \\
\text { CTTGGGCAGAGGTGGGCGGACCCCGCCTCCGGGCCTGGC } \\
\text { GCAACGCTGAGCAGCTGGCGCGTCCCGCGCGGCCCCAGTT } \\
\text { CTGCGCAGCTTCCCGAGGCTCCGCACCAGCCGCGCTTCTGT } \\
\text { CCGCCTGCAGGTAGGGAGCGTGTTCCTCCGCGGGTGCCA } \\
\text { CGGCCCAGTATCTCTGGCTAGCTCGCTGGGCACTTTAGGAC } \\
\text { GGAGGGTCTCTACACCCTTTCTTTGGGATGGAGAGAGGAG } \\
\text { AAGGGAAAGGGAACGCGAT-3'. }\end{array}$ \\
\hline $\begin{array}{l}\text { Stat1-specific siRNA Control- } \\
\text { siRNA }\end{array}$ & $\begin{array}{l}\text { 5'-GGGCAUCAUGCAUCUUACU-3' } 5^{\prime} \text {-UUCUCCGAACGUGUCACGUTT- } \\
3^{\prime}\end{array}$ \\
\hline
\end{tabular}

https://doi.org/10.1371/journal.pone.0228302.t001

Table 2. Real-time PCR primers sequences.

\begin{tabular}{|c|c|}
\hline Gene & primers sequences \\
\hline \multirow[t]{2}{*}{ Stat1 } & Forward: 5' -CAGCTTGACTCAAAATTCCTGGA-3' \\
\hline & Reverse: 5' -TGAAGATTACGCTTGCTTTTCCT-3' \\
\hline \multirow[t]{2}{*}{ NF1 } & Forward: 5' -CGAATCATCACCAATTCCGCA-3' \\
\hline & Reverse: 5' -CCACAACCTTGCACTGCTTTAT-3' \\
\hline \multirow[t]{2}{*}{ Stat3 } & Forward: 5' -ATCACGCCTTCTACAGACTGC-3' \\
\hline & Reverse: $5^{\prime}$-CATCCTGGAGATTCTCTACCACT -3' \\
\hline \multirow[t]{2}{*}{ PAX2 } & Forward: 5'-TCAAGTCGAGTCTATCTGCATCC-3' \\
\hline & Reverse: $5^{\prime}$-CATGTCACGACCAGTCACAAC-3' \\
\hline \multirow[t]{2}{*}{ IRF1 } & Forward: 5'-GCAGCTACACAGTTCCAGG-3' \\
\hline & Reverse: $5^{\prime}$-GTCCTCAGGTAATTTCCCTTCCT -3' \\
\hline \multirow[t]{2}{*}{ Stat4 } & Forward: 5' -TGTTGGCCCAATGGATTGAAA-3' \\
\hline & Reverse: 5' -GGAAACACGACCTAACTGTTCAT-3' \\
\hline \multirow[t]{2}{*}{ PD-L1 } & Forward: 5' -GCTGCACTAATTGTCTATTGGGA-3' \\
\hline & Reverse: 5'-AATTCGCTTGTAGTCGGCACC-3' \\
\hline \multirow[t]{2}{*}{ Actin } & Forward: 5' -CATGTACGTTGCTATCCAGGC-3' \\
\hline & Reverse: 5'-СTCCTTAATGTCACGCACGAT-3' \\
\hline
\end{tabular}

https://doi.org/10.1371/journal.pone.0228302.t002 


\section{Results}

\section{IFN- $\alpha / \gamma$ induce PD-L1 expression in hepatocytes}

We first tested whether IFN- $\alpha$ and IFN- $\gamma$ could affect PD-L1 expression in hepatocytes. As shown in Fig 1A, PD-L1 expression was increased by IFN- $\gamma$ in a dose-dependent manner from 10 to $800 \mathrm{U} / \mathrm{ml} 48 \mathrm{~h}$ after treatment. Similar results were observed for IFN- $\alpha$ (Fig 1B). In vivo experiment, $\mathrm{BALB} / \mathrm{c}$ or $\mathrm{BALB} / \mathrm{c} \mathrm{HBV}$ transgenic mice were intraperitoneally injected with IFN- $\alpha$ or IFN- $\gamma$, and PD-L1 expression in liver tissues were examined by IHC. Treatment with IFN- $\alpha$ or IFN- $\gamma$ induced abrupt increases of PD-L1 levels in both HBV transgenic mice and $\mathrm{BALB} / \mathrm{c}$ mice (Fig $1 \mathrm{C}$ ).

We then determine if IFN- $\alpha / \gamma$ upregulate the expression of PD-L1 by affect its transcription level. Real-time PCR analysis showed that IFN- $\gamma$ pronouncedly increased PD-L1 mRNA levels (Fig 1D). Similar results were observed for IFN- $\alpha$ (Fig 1E).

\section{IFN- $\alpha / \gamma$ induce PD-L1 expression mainly through activation of Stat 1}

The PD-L1 promoter sequence was subjected to bioinformatics analysis (http://gpminer.mbc. nctu.edu.tw/), revealing that there are several putative transcription factor binding sites in the promoter region, including sites for Stat1, NF1, Stat3, PAX2, IRF1 and Stat4 (Fig 2A). We next tested the effect of IFN- $\gamma$ or IFN- $\alpha$ on expression of these transcription factors. L02 cells stimulated with IFN- $\gamma$ for $24 \mathrm{~h}$, and Stat 1 mRNA level was the mostly increased (around 10 times) compared to the other transcription factors (Fig 2B). Same results were obtained for IFN- $\alpha$ treatment (Fig 2C). The protein expression of Stat1 and its phosphorylation were also stimulated by IFN- $\gamma$ or IFN- $\alpha$ (Fig 2D). We mutated the core site CTGAT of Stat 1 binding site on the PD-L1 promoter to ACTGC and named it as PD-L1-mut (Fig 2A). As shown in Fig 2E and 2F, Stat1 overexpression by transfection with the plasmid pCMV-Stat1 in L02 cells led to an obvious increase in the wild-type but not mutant PD-L1 promoter activity ( 3.5-fold) $(\mathrm{P}<0.001)$ and significant elevation of cell membrane PD-L1 levels. PD-L1 promoter activity was increased by Statl in a dose dependent manner (Fig 2G). These results indicate that IFN$\alpha / \gamma$ upregulates the key PD-L1 transcription factor Stat1.

To further determine the role of Stat1 in IFN- $\alpha / \gamma$-induced PD-L1 expression, L02 cells were transfected with PD-L1 luciferase reporter plasmid with a wild type or mutated Stat 1 binding site and incubated with IFN- $\gamma$ for $48 \mathrm{~h}$. As seen in Fig 3A, IFN- $\gamma$ treatment increased the activity of wild type but not the mutated promoter. Moreover, Stat 1 depletion by siRNA or its inhibitor fludarabine largely abolished IFN- $\boldsymbol{\gamma}$-induced PD-L1 promoter activation (Fig 3B). Similar results were observed for IFN- $\alpha$ (Fig 3C and 3D).

Similarly, PD-L1 upregulation by IFN- $\alpha / \gamma$ was mostly abrogated under Stat 1 depletion by siRNA or inhibition by fludarabine (Fig 4A and 4B). Inhibition of Stat1 and p-Stat1 by fludarabine was confirmed by western blot (Fig 4C). Similar results were observed in total PD-L1 mRNA levels and protein levels (Fig 4D). In addition, treatment with IFN- $\alpha$ or IFN- $\gamma$ induced abrupt increases of PD-L1 levels in BALB/c mice, which was observably suppressed by fludarabine (Fig 4E). Based on these results, it can be demonstrated that IFN-induced PD-L1 expression is mainly via upregulation and activation of its transcription factor Stat1.

\section{Blockage of PD-L1/PD-1 interaction enhances the HBV-specific T cell response and facilitates viral clearance in $\mathrm{HBV}$ transgenic mice}

Finally, based on our previous studies showing that a heat shock protein gp96-based therapeutic vaccine induces a potent antiviral T cell response in HBV transgenic mice [24, 25], we further investigated possible synergy between the therapeutic vaccine and PD-L1/PD-1 blockage 
A

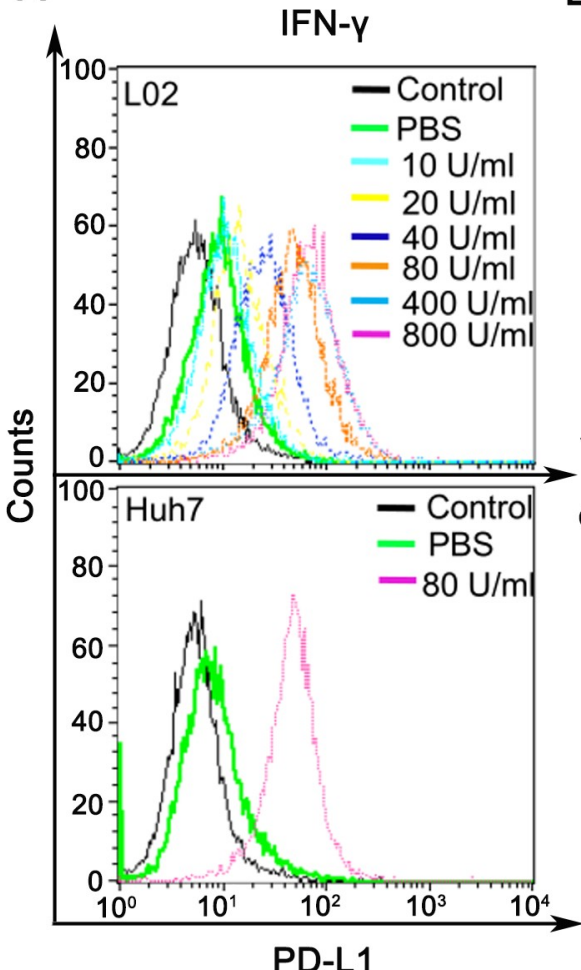

PD-L1

C
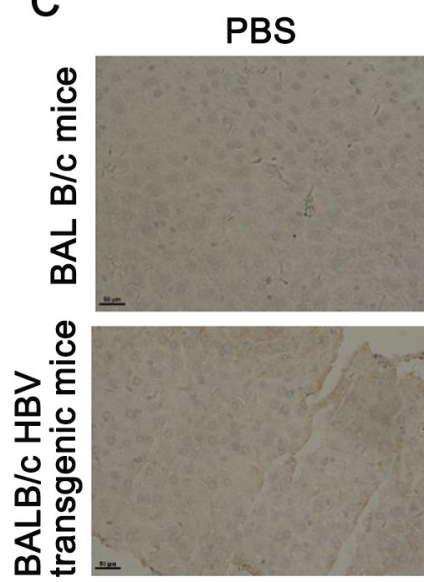

IFN- $\alpha$

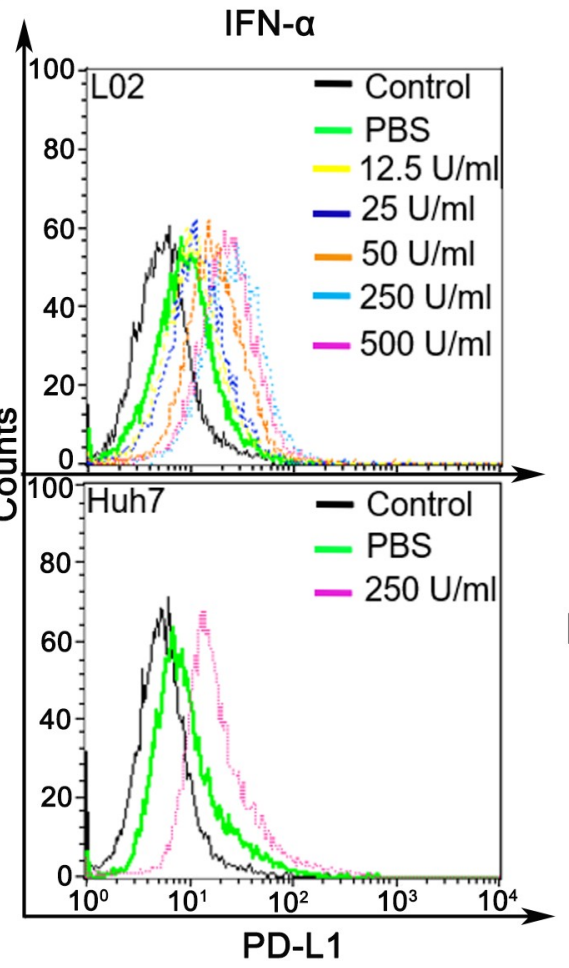

IFN- $\alpha$
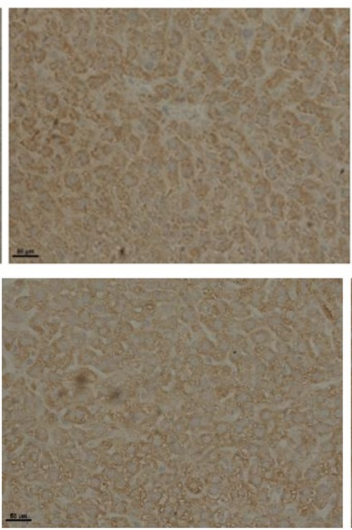

IFN-Y
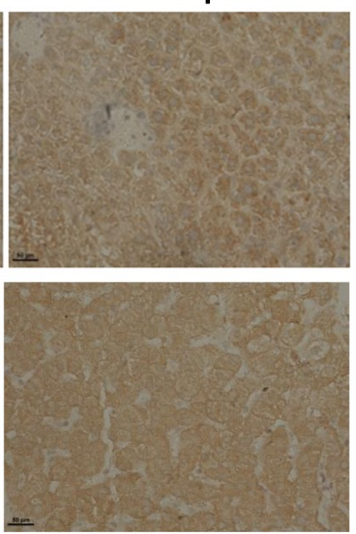

D

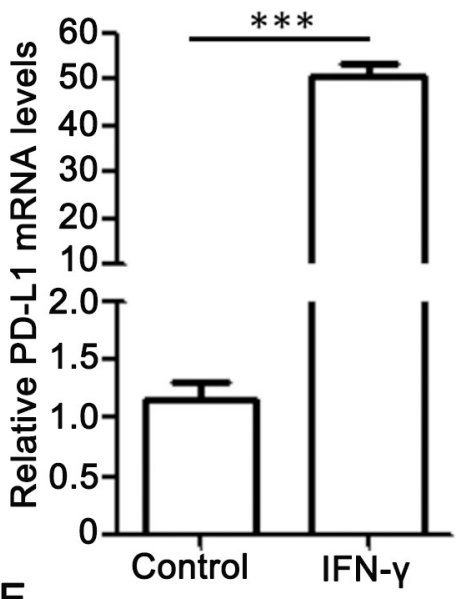

E

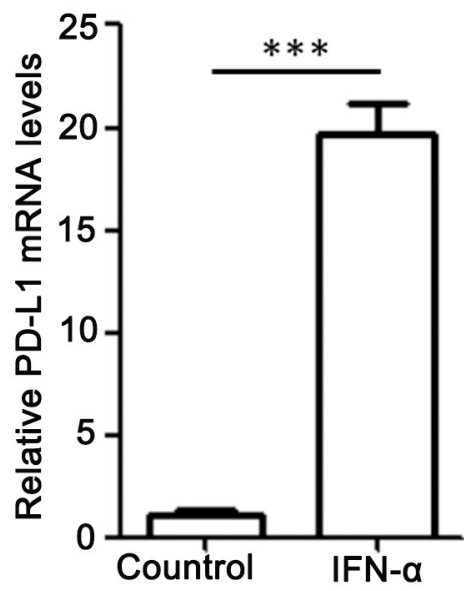

PD-L1

Fig 1. Effect of IFN- $\gamma$ and IFN- $\alpha$ on PD-L1 expression both in vitro and in vivo. (A and B) L02 and Huh7 cells were treated with IFN- $\gamma$ (A) or IFN- $\alpha$ (B) at indicated concentrations for $48 \mathrm{~h}$. Flow cytometric analysis was performed to detect cell membrane PD-L1 levels. Cells stained with control IgG served as a negative control. (C) BALB/c or BALB/c HBV transgenic mice were treated with PBS, IFN- $\alpha$, IFN- $\gamma$, as described in Materials and Methods. IHC analysis was performed for detection of PD-L1 expression levels in mouse livers. Scale bars, $50 \mu \mathrm{m}$. (D and E) Realtime PCR analysis of PD-L1 mRNA levels in L02 cells treated with IFN- $\gamma(\mathrm{D})$ or IFN- $\alpha$ (E) or PBS as control for $48 \mathrm{~h}$. The relative mRNA levels of PD-L1 were normalized to the housekeeping gene actin. Data are presented as mean \pm SD for three independent experiments. ${ }^{* * *} p<0.001$ compared to the control.

https://doi.org/10.1371/journal.pone.0228302.g001

on induction of anti-HBV T cell immunity. HBV transgenic mice were vaccinated with gp96 vaccine containing gp96 adjuvant, $\mathrm{HBsAg}$ and $\mathrm{HBcAg}$, along with four doses treatment with 
A

-360 CAAAGCCATATGGGTCTGCTGCTGACTTTTTATATGTTGTAGAGTTATATCAAGTTATGTCAA ACTGC

-297 GATGTTCAGTCACCTTGAAGAGGCTTTTATCAGAAAGGGGGACGCCITTCTGATAAAGGTT Stat1 -234 AAGGGGTAACCTTAAGCTCTTACCCCTCTGAAGGTAAAATCAAGGTGCGTTCAGATGTTGG NF1 -171 CTTGTTGTAAATTTCTTTTTTTATTAATAACATACTAAATGTGGATTTGCTTTAATCTTCGAAA

-108 CTCTTCCCGGTGAAAATCTCATTTACAAGAAAACTGGACTGACATGTITCACTTTCTGTTTCA Stat3 PAX2 IRF1

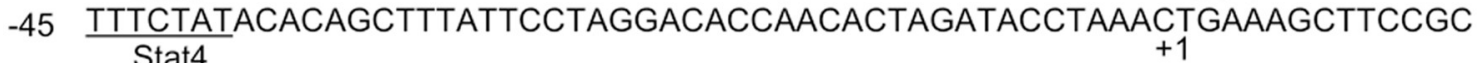

18 CGATTTCACCGAaggtCAgGAAAGTCCAACGCCCGgCAAACTGGATTTGCTGCCTTG

B

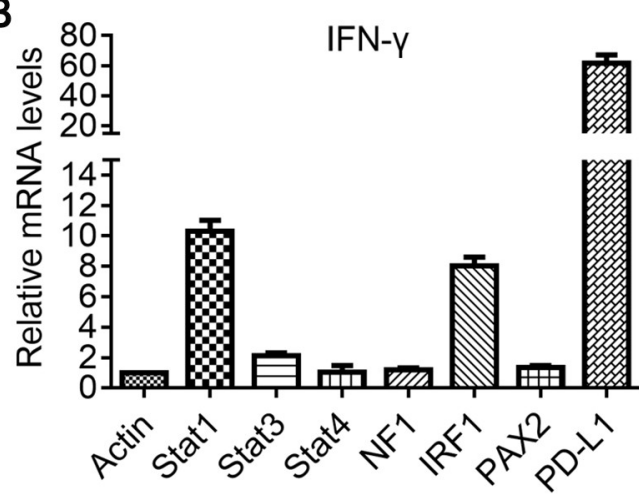

D

Stat1

$$
\begin{array}{llll}
1.0 & 1.8 & 1.0 & 1.4
\end{array}
$$

p-Stat1

$$
\begin{array}{llll}
1.0 & 6.6 & 1.0 & 5.3
\end{array}
$$

Actin

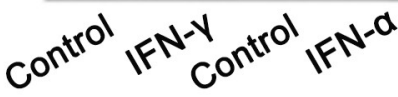

C

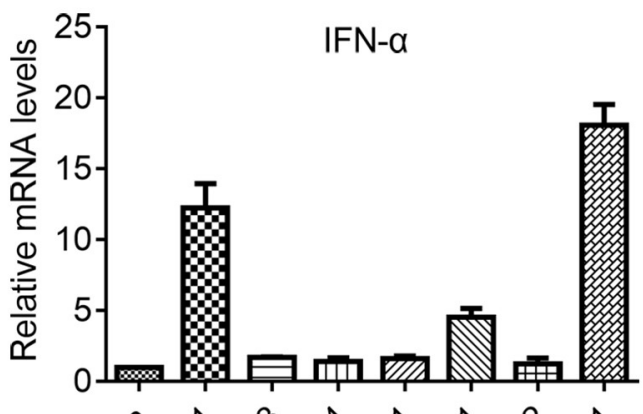

$$
\text { E }
$$<smiles>[CH-]1CCCC1</smiles>

PD-L1-wt+pCMV PD-L1-wt+Stat1
F

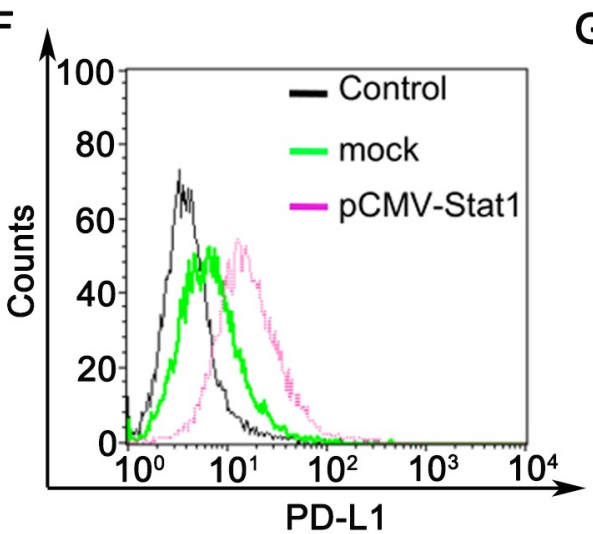

G

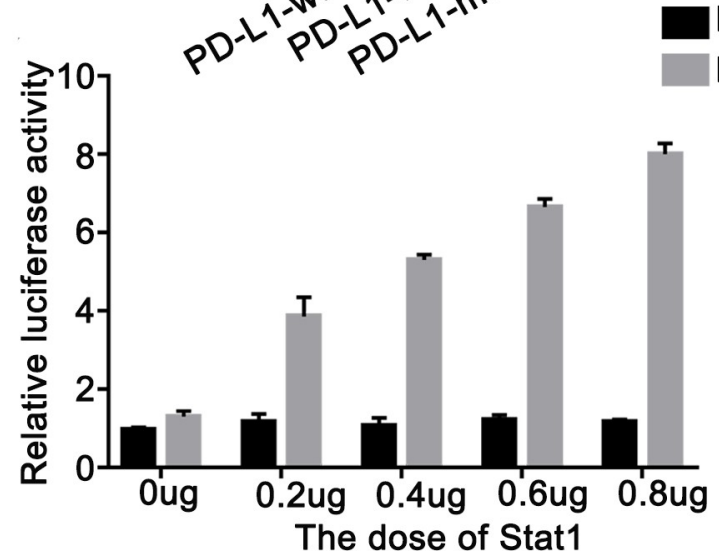

Fig 2. Identification of Stat 1 as a key transcription factor of PD-L1 induced by IFN- $\alpha / \gamma$. (A) Sequence analysis of the PD-L1 promoter was performed online at http://gpminer.mbc.nctu.edu.tw/. The putative binding sites for several cis-acting elements are indicated. The mutations 
within Stat1 binding site were shown by italic letters. (B and C) Real-time PCR analysis of mRNA levels of putative transcription factors in L02 cells treated with IFN- $\alpha$ (B) or IFN- $\gamma(\mathrm{C})$ or PBS as control for $24 \mathrm{~h}$. The mRNA levels of control were arbitrarily set as 1.0. (D) L02 cells treated with $80 \mathrm{U} / \mathrm{ml} \mathrm{IFN- \gamma}$ or $50 \mathrm{U} / \mathrm{ml}$ IFN- $\alpha$ or PBS as control for $48 \mathrm{~h}$ and Stat 1 and phosphorylated Stat 1 (p-Stat1) levels were determined by western blot. (E) L02 cells were co-transfected with PD-L1 promoter luciferase reporter plasmid with a wild type (PD-L1 wt) or mutated Stat1 binding site (PD-L1 mut) and pCMV-Stat1 (Stat1) or pCMV as a mock. The relative luciferase activity was determined using dual luciferase assay kit $48 \mathrm{~h}$ later. (F) Cell membrane PD-L1 levels in L02 cells transfected with pCMV-Stat1 were determined by flow cytometry. (G) L02 cells were co-transfected with PD-L1 promoter luciferase reporter plasmid (PD-L1 wt) and different doses of pCMV-Stat1 (Stat1) or pCMV as a mock. The relative luciferase activity was determined using dual luciferase assay kit $48 \mathrm{~h}$ posttransfection. Data are presented as mean $\pm \mathrm{SD}$ for three independent experiments. ${ }^{* * *} p<0.001$ compared to the control.

https://doi.org/10.1371/journal.pone.0228302.g002

an anti-PD-1 mAb. As shown in Fig 5B, gp96-based therapeutic vaccine induced IFN- $\gamma$-secreting $\mathrm{CD}^{+}$and $\mathrm{CD}^{+} \mathrm{T}$ cells in mouse livers, and importantly, co-treatment with anti-PD-1 $\mathrm{mAb}$ resulted in a significant increase in IFN- $\boldsymbol{\gamma}$-secreting $\mathrm{T}$ cells compared to the vaccine alone(all $\mathrm{P}<0.05$ or 0.01 ). Similar results were obtained in ELISPOT assay (Fig 5C). Besides, significant increases of antiviral $\mathrm{T}$ cell responses in the spleen of immunized mice were also observed under treatment with anti-PD-1 mAb (Fig 5D and 5E).

Significant decreases in serum HBV DNA and HBsAg levels were observed in gp96 vaccine-immunized mice treated with anti-PD-1 mAb compared to untreated mice (both $P<0.05$ ) (Fig 6A and 6B). Mice receiving the combined treatment of gp96 vaccine with anti$\mathrm{PD}-1$ exhibited significantly reduced hepatic $\mathrm{HBcAg}$ expression compared to either treatment alone (anti-PD- 1 vs anti-PD-1+gp96 vaccine, $53 \pm 7.6$ vs $4 \pm 1, \mathrm{P}<0.001$; gp96 vaccine vs anti$\mathrm{PD}-1+\mathrm{gp} 96$ vaccine, $20 \pm 3$ vs $4 \pm 1, \mathrm{P}<0.001$ ) (Fig $6 \mathrm{C}$ ). Moderate elevation of the serum ALT levels was observed in anti-PD-1 mAb-treated and gp96 vaccine-immunized mice (Fig 6D). Taken together, these data indicate that blockage of the interaction between PD-1 and PD-L1 which expression may be upregulated by IFN- $\gamma$-secreting $\mathrm{CD} 8^{+}$and $\mathrm{CD} 4^{+} \mathrm{T}$ cells significantly enhances vaccine-mediated $\mathrm{T}$ cell response against $\mathrm{HBV}$.

\section{Discussion}

In this study, our findings identified Stat1 as the key transcription factor for hepatic PD-L1 expression through its phosphorylation induced by IFN- $\alpha / \gamma$. Importantly, the blockage of PD-L1/PD-1 enhanced vaccine-induced antiviral T cell responses in HBV transgenic mice. Therefore, we present a new model in which IFN- $\alpha / \gamma$ activates Stat 1 which promotes PD-L1 transcription and expression, and elevated PD-L1 expression in liver may contribute to impaired $\mathrm{T}$ cell responses, hampering the development of the virus-specific immune response in $\mathrm{CHB}$.

Previous studies show that PD-L1 expression is regulated by the transcription factor Stat3 in $\mathrm{T}$ cell lymphoma and NF- $\mathrm{KB}$ in myelodysplastic syndromes blasts $[28,29]$. Besides, in melanoma cells treated with IFN- $\gamma$, the activated IRF1 binds to the promoter of PD-L1 to regulate its PD-L1 [30-32]. In screening of potential transcription factors of PD-L1 in hepatocytes we found that Stat1 induced the most significant upregulation of PD-L1, suggesting that the regulation of PD-L1 expression can be exquisitely cell-type specific. In this study, IFN- $\alpha / \gamma$ pronouncedly promoted hepatic Stat1 phosphorylation both in vitro and in mice, likely through the Jak/Stat1 pathway [33,34]. Furthermore, inhibition of Stat 1 activation by its inhibitor or Stat1 depletion by RNAi largely abolished IFN- $\alpha / \gamma$-mediated PD-L1 upregulation. Our results therefore indicate that Stat 1 acts as a major transcription factor in IFN- $\alpha / \gamma$-induced PD-L1 elevation in liver. Besides Stat1, we observed an increase of IRF1 expression in IFN- $\alpha / \gamma$-treated hepatocytes (Fig $2 \mathrm{~B}$ ), and IFN- $\alpha / \gamma$ could moderately enhance the activity of PD-L1 luciferase reporter with the mutated Stat1 binding site (Fig 3A and 3C). The results indicate that IRF1 may play a minor role in IFN- $\alpha / \gamma$-mediated PD-L1 upregulation. 
A

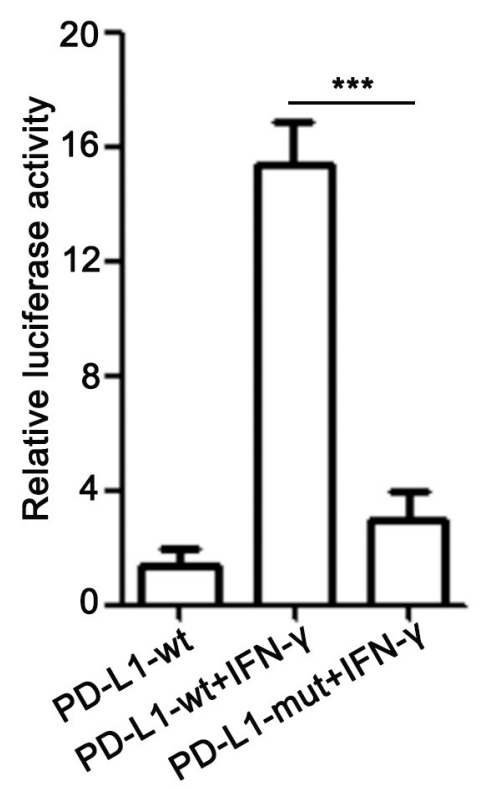

C

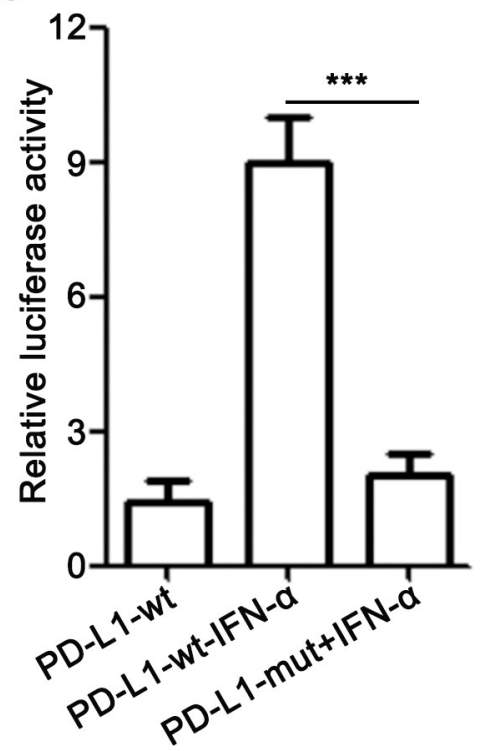

B

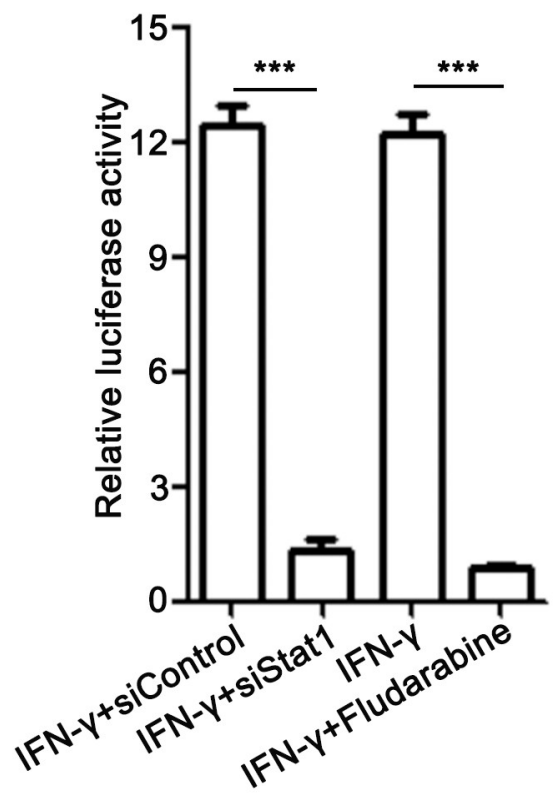

D

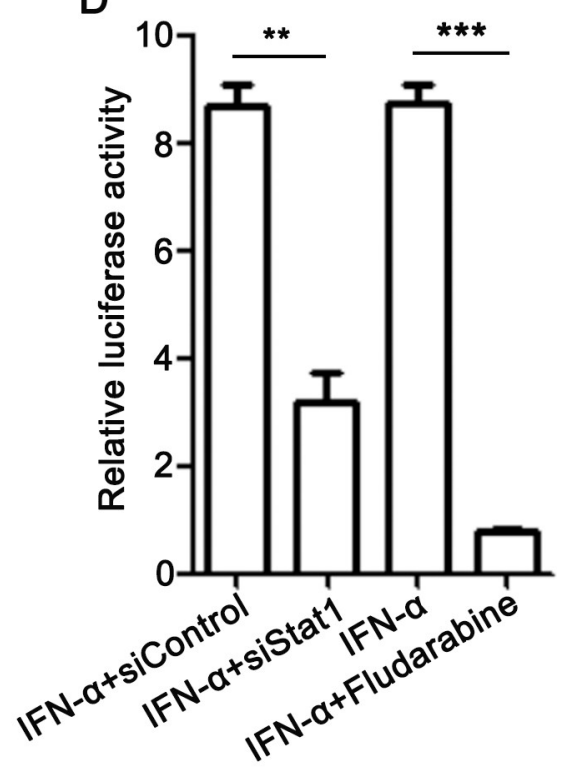

Fig 3. IFN- $\alpha / \gamma$ upregulate PD-L1 expression in a Stat1 dependent manner. (A and C) L02 cells were transfected with PD-L1 promoter luciferase reporter plasmid with a wild type or mutated Stat1 binding site and incubated with 80 $\mathrm{U} / \mathrm{ml} \mathrm{IFN-} \gamma$ (A) or $50 \mathrm{U} / \mathrm{ml}$ IFN- $\alpha$ (C) for $48 \mathrm{~h}$. (B and D) L02 cells transfected with PD-L1 promoter luciferase reporter plasmid were co-treated with IFN- $\gamma(\mathrm{B})$ or IFN- $\alpha$ (D) and Stat 1 siRNA or fludarabine $(5 \mu \mathrm{g} / \mathrm{ml})$ for $48 \mathrm{~h}$. The relative luciferase activity was determined using dual luciferase assay. Data are presented as mean \pm SD for three independent experiments. ${ }^{* *} p<0.01$, and ${ }^{* * *} p<0.001$ compared to the control.

https://doi.org/10.1371/journal.pone.0228302.g003

IFN- $\gamma$ and TNF- $\alpha$, produced by T cells, reduce levels of HBV cccDNA in hepatocytes by inducing deamination and subsequent cccDNA decay [35]. However clinical evidence shows that the CD8+ T cells in CHB patients lose their antiviral function and ability to proliferate, which is characterized by $\mathrm{T}$ cell exhaustion, suppressed cytokine production and excessive inhibitory signals [36-38]. The co-inhibitory receptor PD-1, expressed on T-cells, delivers 
A
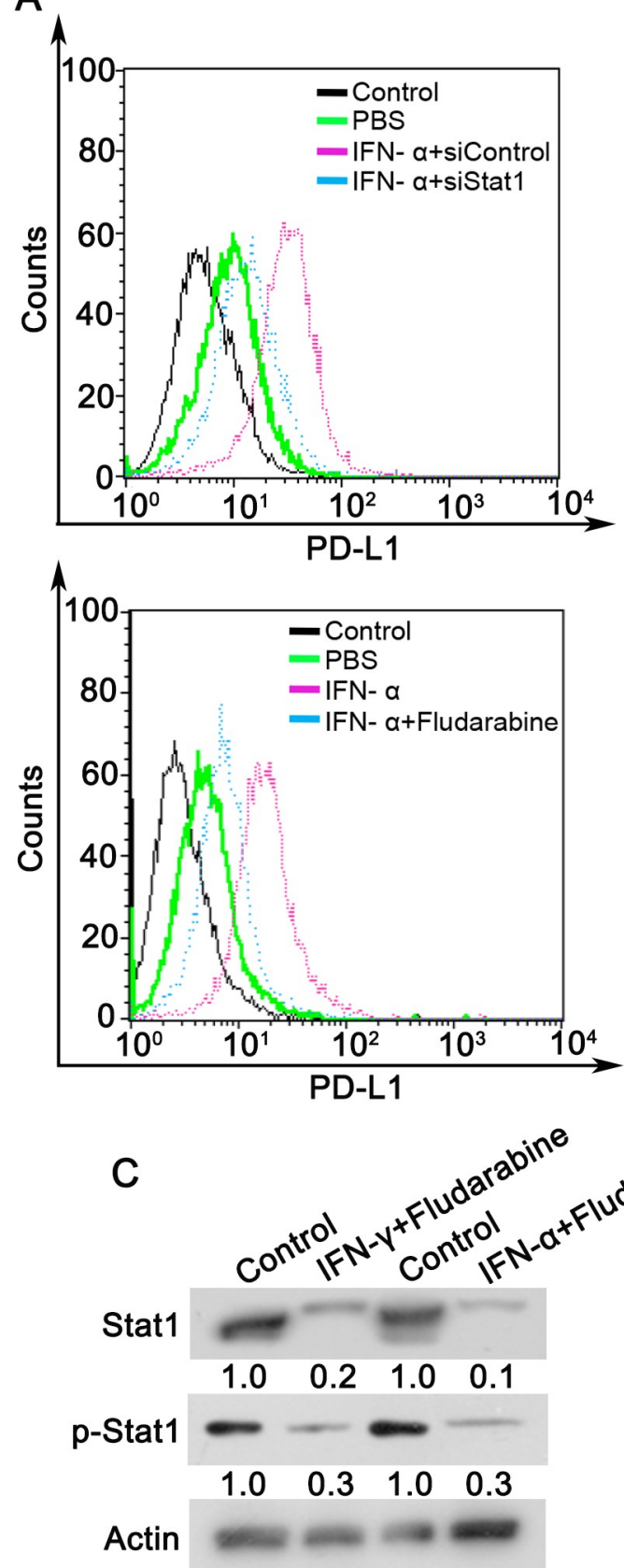

E

PBS

$\frac{d}{\frac{d}{\varepsilon}}$
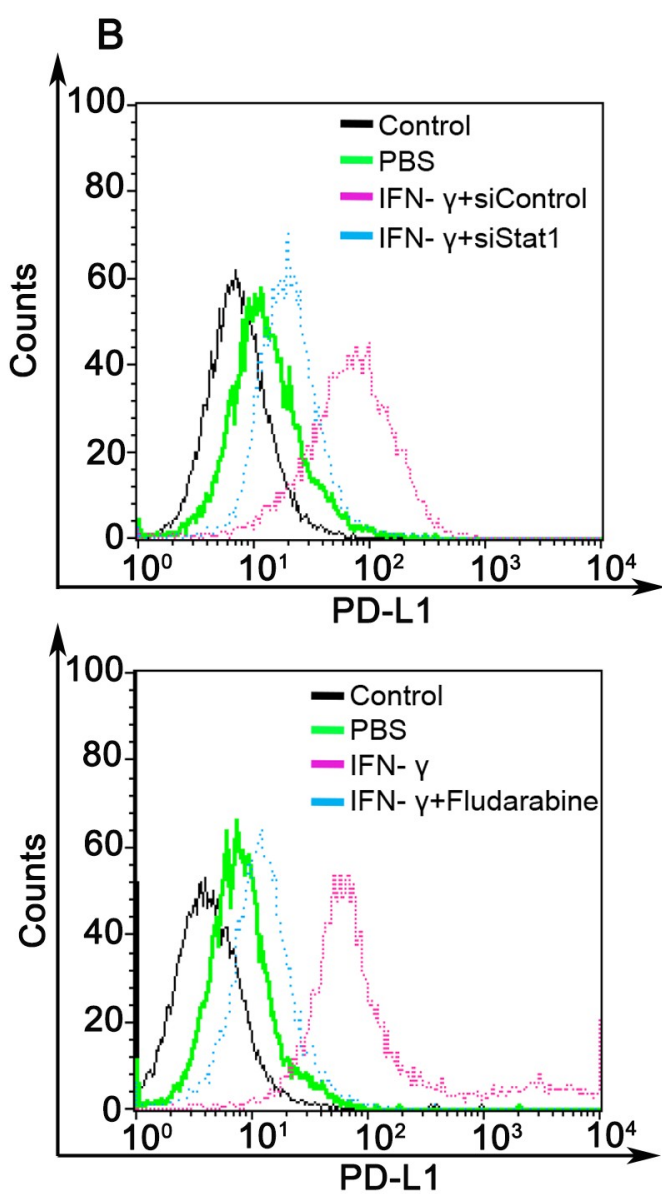

D

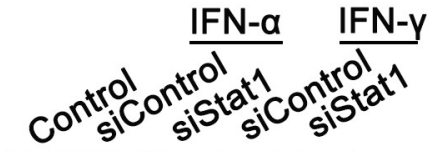

PD-L1 mRNA

Actin

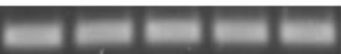

PD-L1 protein

Actin
IFN-Y

IFN- $y+$ Fludarabine

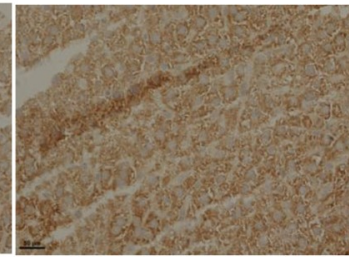

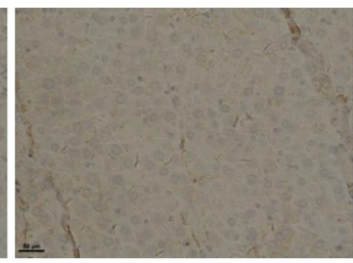

PD-L1

Fig 4. Inhibition of Stat 1 abrogates IFN- $\alpha / \gamma$-induced upregulation of PD-L1. (A and B) Cell membrane PD-L1 levels were detected by flow cytometry in L02

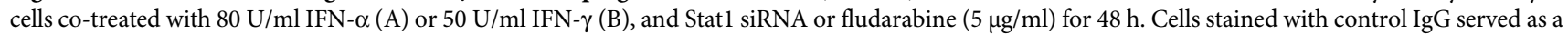


negative control. (C and D) L02 cells co-treated with $80 \mathrm{U} / \mathrm{ml} \mathrm{IFN-} \alpha$ or $50 \mathrm{U} / \mathrm{ml} \mathrm{IFN-} \gamma$, with or without fludarabine ( $5 \mu \mathrm{g} / \mathrm{ml})$ or Stat 1 siRNA for $48 \mathrm{~h}$. Stat 1 and phosphorylated Stat1 (p-Stat1) in cells co-treated with or without (control) fludarabine were determined by western blot (C). The mRNA and protein levels of PD-L1 were analyzed using real-time PCR and western blotting, respectively (D). (E) BALB/c mice were treated with PBS, IFN- $\alpha$, and IFN- $\gamma$, and fludarabine as described in Materials and Methods. IHC analysis was performed for detection of PD-L1 expression levels in mouse livers. Scale bars, $50 \mu \mathrm{m}$. The experiments were performed twice with similar results.

https://doi.org/10.1371/journal.pone.0228302.g004

negative signals when engaged by its ligand PD-L1, expressed on dendritic cells, macrophages, endothelial cells and hepatocytes; to attenuate $\mathrm{T}$ cell activation, effector functions and survival [39]. Recent studies show that PD-1/PD-L1 pathway contributes to the suppression of $\mathrm{HBV}$-specific $\mathrm{T}$ cell function in both $\mathrm{HBV}$ transgenic mice and $\mathrm{CHB}$ patient [4, 40-43]. In addition, treatment with anti-PD-1 or anti-PD-L1 mAbs results in the enhancement or restoration of antiviral $\mathrm{T}$ cell function in mice [40, 41, 44-46]. Furthermore, blockage of the interaction between PD-1 and PD-L1 by specific antibodies also leads to restoration of $\mathrm{HBV}$-specific $\mathrm{T}$ cell function, enhanced antiviral immunity, and $\mathrm{HBs} \mathrm{Ag}$ decline in CHB [44, 45, 47-49]. In this study, we found that the IFN- $\alpha / \gamma$-Stat 1 axis may play a role and serve as a potential drug target for hepatic PD-L1 expression which may lead to $\mathrm{T}$ cell inactivation, and blockage of $\mathrm{PD}-1 / \mathrm{PD}-\mathrm{L} 1$ reversed liver-infiltrating virus-specific T cell activity and enhanced gp96 vaccine-induced antiviral efficiency in HBV transgenic mice.

In this study we found that IFN- $\gamma$ pronouncedly promoted hepatic PD-L1 expression so it is conceivable that in CHB hepatocytes may predispose intrinsic defects in hyporesponsiveness of virus-specific IFN- $\gamma$-secreting CD8+ and CD4+ T cells by upregulation of PD-L1 expression in liver. PD-L1 overexpression may protect HBV-infected hepatocytes from $\mathrm{T}$ cell-mediated viral inhibition, which underlies the need for a combination strategy to directly activate $\mathrm{T}$ cells by vaccination and block PD-L1/PD-1-mediated immune suppression for optimal anti-HBV immunity.

Meanwhile, it is possible that PD-L1 may exert beneficial effects by preventing overactivation of inflammation and $\mathrm{T}$ cell responses in $\mathrm{CHB}[50,51]$. More studies are needed to dissect the immunoregulatory mechanisms of PD-L1 in various States of HBV infection, and its use as a potential prognostic marker in disease progression as seen in cancer patients [7].

IFN- $\alpha$, the first drug licensed to treat HBV infection, has been extensively used as one of the major standard treatments for CHB $[14,15,52,53]$. IFN- $\alpha$ promotes $\mathrm{T}$ cell response by stimulating cell expansion, differentiation and cytolytic function. In addition, it also has a direct antiviral effect by accelerating decay of viral capsids and inducing antiviral IFN-stimulated genes (ISGs) [54]. In this study, we found that IFN- $\alpha$ significantly enhances PD-L1 expression in mouse livers, which may negatively affect the anti-HBV efficiency of IFN- $\alpha$. Our current work may provide further dissection of the limited effectiveness of therapeutic IFN- $\alpha$ in $\mathrm{CHB}$ and beneficial help in the design of a more efficient combined anti-HBV therapy for this first-line drug.

In conclusion, our study provides further understanding of IFN- $\alpha / \gamma$-induced PD-L1 function in the complex regulatory networks that orchestrate $\mathrm{T}$ cell immune defects in chronic viral infections. Given the broad immunoinhibitory function of PD-L1 and current promising anti-PD-L1/PD-1 therapies in cancer, our work provides valuable insights into IFN-induced PD-L1 elevation in hepatic microenvironment immunotolerance and raises further potential interest in enhancing the anti-HBV efficacy of therapeutic HBV vaccines and IFN- $\alpha$ by blocking PD-L1/PD-1. 

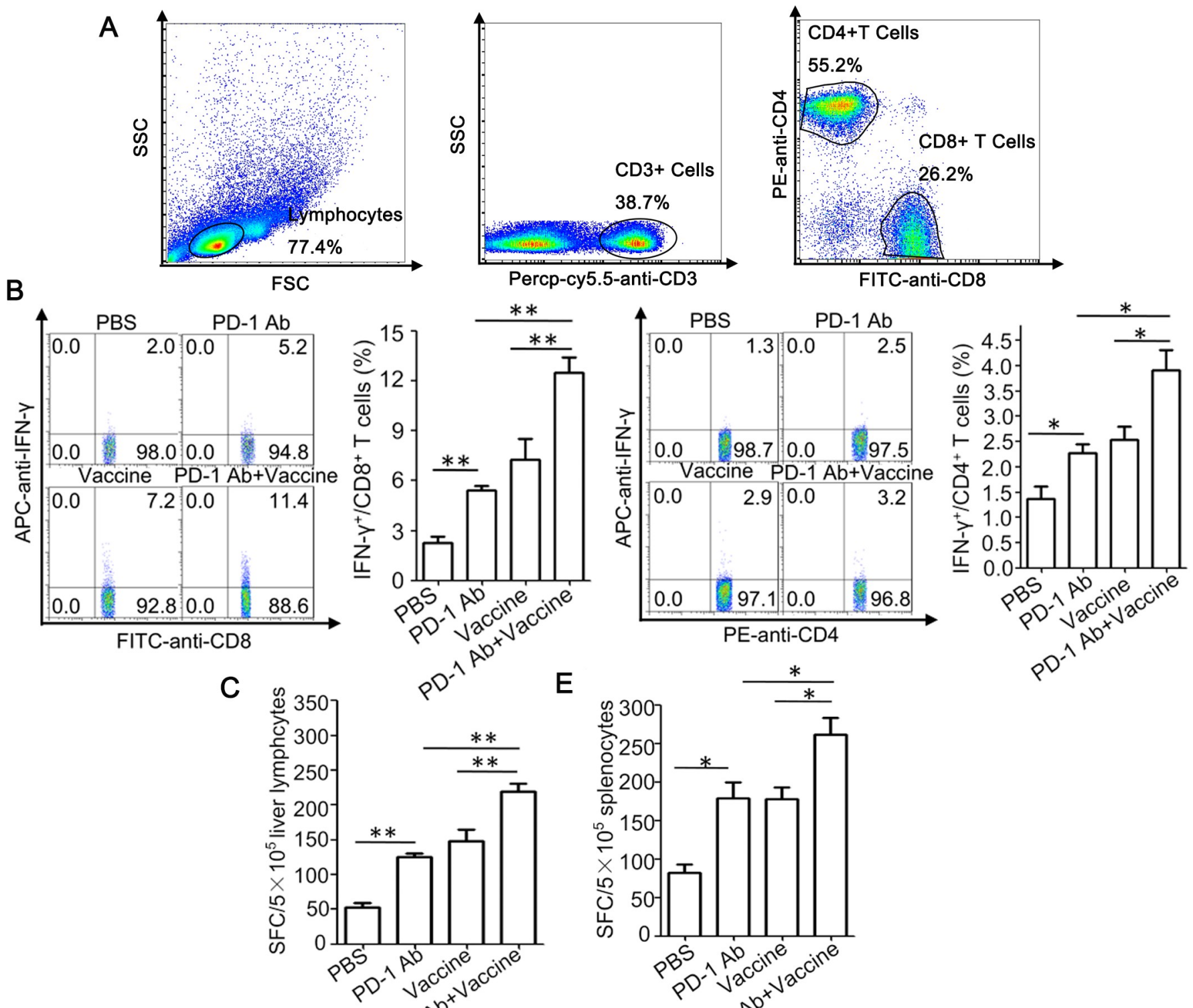

E
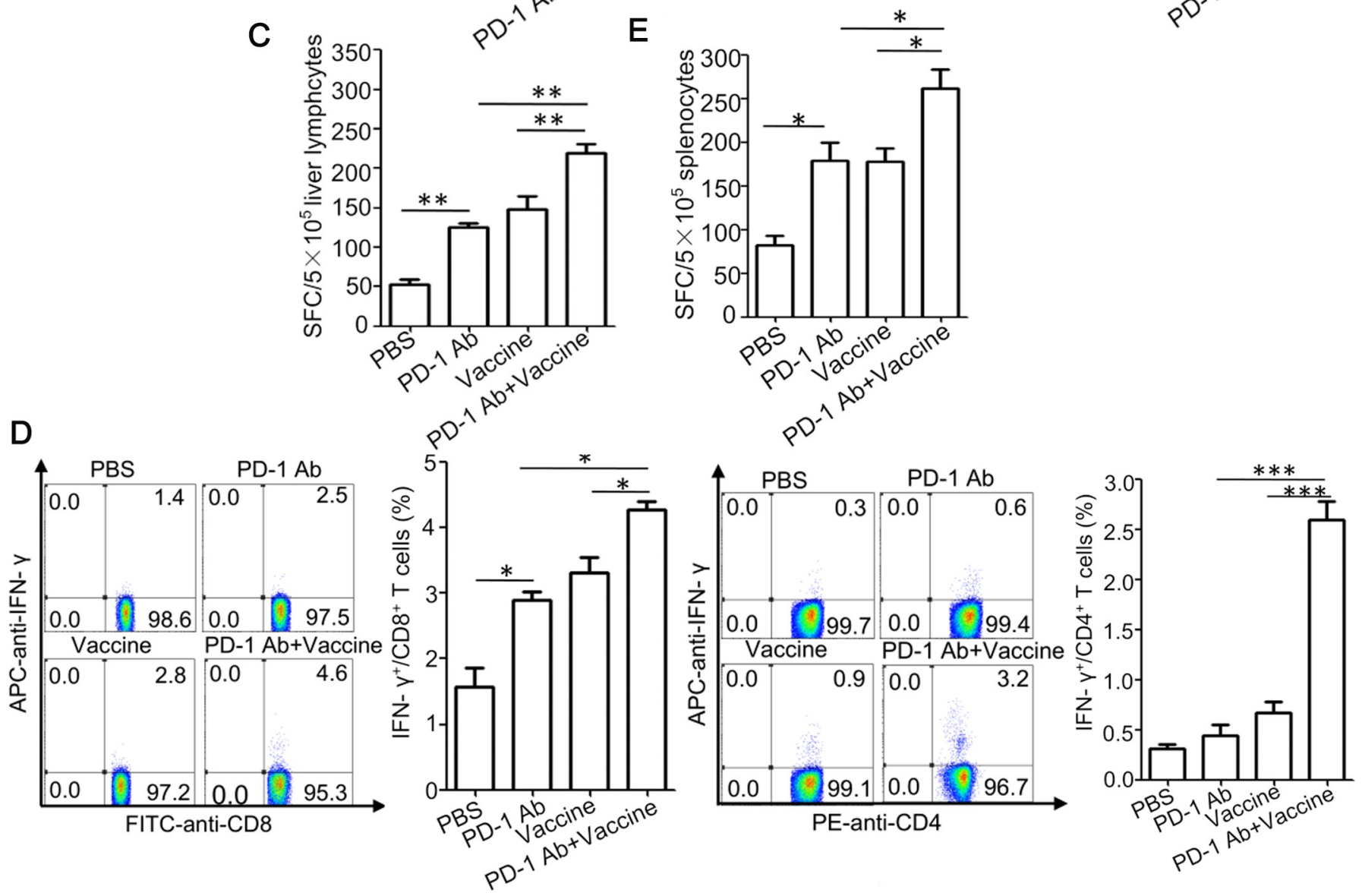
Fig 5. Anti-PD-1 mAb treatment enhances the HBV-specific $\mathrm{T}$ cell responses induced by gp96 therapeutic vaccine in $\mathrm{HBV}$ transgenic mice. $\mathrm{HBV}$ transgenic mice were immunized with the therapeutic vaccine containing $\mathrm{HBsAg}, \mathrm{HBcAg}$, and gp96 adjuvant at wks 1, 2, and 4, and/or treated with anti-PD-1 mAb (n = 5 mice/group). Mice were sacrificed at wk 9 for immunological analysis. The gating strategy for CD4 ${ }^{+}$and $\mathrm{CD} 8{ }^{+} \mathrm{T}$ cells in lymph nodes and splenic lymphocytes by flow cytometry(A). Flow cytometric analysis was performed to quantify IFN $\gamma^{+} \mathrm{CD} 8^{+}$or IFN $\gamma^{+} \mathrm{CD} 4^{+} \mathrm{T}$ cell populations in the liver (B) or spleen (D) of mice. For IFN- $\gamma$ ELISPOT assay, lymphocytes from liver (C) or spleen (E) $\left(5 \times 10^{5}\right.$ cells $/$ well) were stimulated with $\mathrm{HBsAg} / \mathrm{HBcAg}(5 \mu \mathrm{g} / \mathrm{ml}$ each), or BSA as a negative control for background evaluation. Data are presented as the mean $\pm \mathrm{SD}$ for five mice from two independent experiments. ${ }^{*} P<0.05,{ }^{* *} P<0.01$, and ${ }^{* * *} P<0.001$ using t-tests.

A

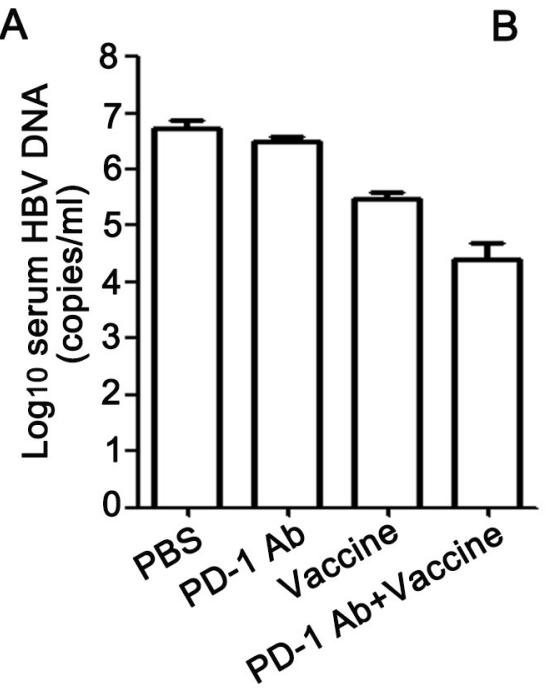

C PBS

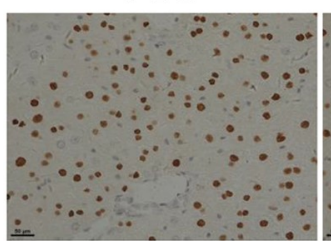

PD-1 Ab

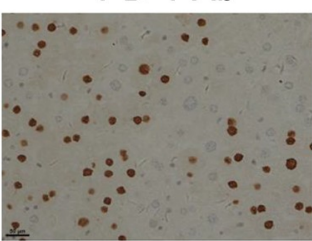

气્心

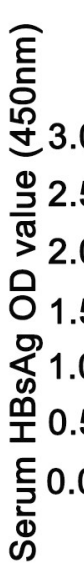

- PBS

- PD-1 Ab

* Vaccine $3.0 \rightarrow-P D-1 A b+V a c c i n e$

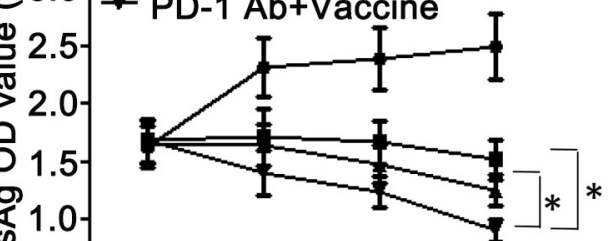

界 0.5 -
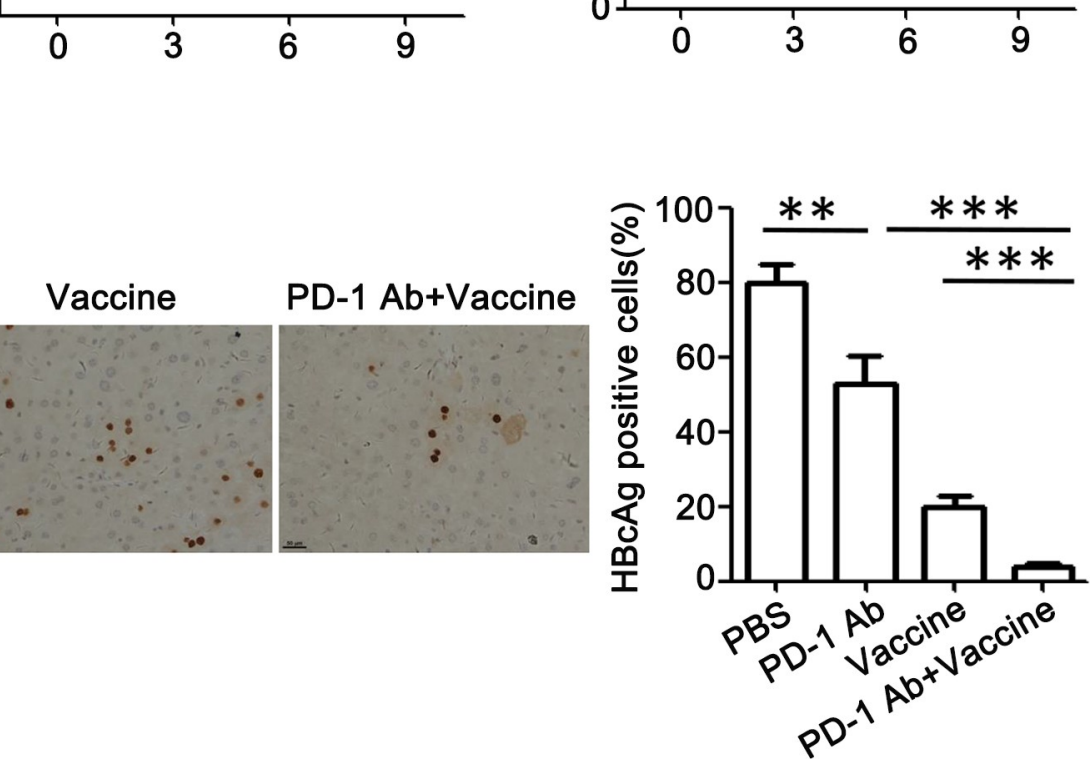

Fig 6. Suppression of HBV expression and replication by gp 96 the therapeutic vaccine is enhanced by treatment with anti-PD-1 mAb. HBV transgenic mice were immunized and treated as in Fig 5. Mice were sacrificed at wk 9 for virological analysis. (A) Serum HBV DNA levels were quantified by real-time PCR. (B) Serum HBsAg was detected by ELISA at wks 0, 3, 6, 9, respectively. (C) IHC analysis of HBcAg expression in mouse liver tissues. The HBcAg-positive hepatocytes were counted in ten random fields under the microscope and the average number was calculated. Scale bars, $50 \mu \mathrm{m}$. (D) Serum ALT levels were detected by ELISA at wks $0,3,6$, 9. Data are presented as the mean \pm SD for five mice from two independent experiments. ${ }^{*} \mathrm{P}<0.05$, ${ }^{* *} \mathrm{P}<0.01$, and ${ }^{* * *} \mathrm{P}<0.001$ using t-tests.

https://doi.org/10.1371/journal.pone.0228302.g006

\section{Supporting information}

S1 Fig. Raw images for Fig 1C.

(PDF)

S2 Fig. Raw images for Fig 2D.

(PDF) 
S3 Fig. Raw images for Fig 4C, 4D and 4E.

(PDF)

\section{Acknowledgments}

The authors are grateful to Beijing Combio Company for the anti-PD-1 monoclonal antibody $(\mathrm{mAb})$. and thankful to Beijing Tiantan Biological Products Company for the HBs protein.

\section{Author Contributions}

Conceptualization: Songdong Meng.

Formal analysis: LanLan Liu, Junwei Hou.

Funding acquisition: Songdong Meng.

Investigation: LanLan Liu, Junwei Hou, Yuxiu Xu, Lijuan Qin, Weiwei Liu, Han Zhang, Yang Li, Mi Chen, Mengmeng Deng, Bao Zhao, Jun Hu, Huaguo Zheng.

Supervision: Songdong Meng.

Writing - original draft: LanLan Liu, Junwei Hou.

Writing - review \& editing: Changfei Li, Songdong Meng.

\section{References}

1. Knolle PA, Thimme R. Hepatic immune regulation and its involvement in viral hepatitis infection. Gastroenterology. 2014; 146(5):1193-207. https://doi.org/10.1053/j.gastro.2013.12.036 PMID: 24412289

2. Han $Q$, Lan $P$, Zhang J, Zhang C, Tian Z. Reversal of hepatitis B virus-induced systemic immune tolerance by intrinsic innate immune stimulation. Journal of gastroenterology and hepatology. 2013; 28:132-7. https://doi.org/10.1111/jgh.12034 PMID: 23855309

3. Schurich A, Khanna P, Lopes AR, Han KJ, Peppa D, Micco L, et al. Role of the coinhibitory receptor cytotoxic T lymphocyte antigen-4 on apoptosis-Prone CD8 T cells in persistent hepatitis B virus infection. Hepatology. 2011; 53(5):1494-503. https://doi.org/10.1002/hep.24249 PMID: 21360567

4. Sung PS, Park DJ, Kim J-H, Han JW, Lee EB, Lee GW, et al. Ex vivo detection and characterization of hepatitis $B$ virus-specific CD8+ T cells in patients considered immune tolerant. Frontiers in Immunology. 2019; 10.

5. Chen JH, Perry CJ, Tsui Y-C, Staron MM, Parish IA, Dominguez CX, et al. Prostaglandin E2 and programmed cell death 1 signaling coordinately impair CTL function and survival during chronic viral infection. Nature medicine. 2015; 21(4):327. https://doi.org/10.1038/nm.3831 PMID: 25799228

6. Manigold T, Racanelli V. T-cell regulation by CD4 regulatory T cells during hepatitis $B$ and $C$ virus infections: facts and controversies. 2007.

7. Ostrand-Rosenberg S, Horn LA, Haile ST. The programmed death-1 immune-suppressive pathway: barrier to antitumor immunity. Journal of immunology (Baltimore, Md: 1950). 2014; 193(8):3835-41.

8. Cabrera R, Tu Z, Xu Y, Firpi RJ, Rosen HR, Liu C, et al. An immunomodulatory role for CD4(+)CD25(+) regulatory T lymphocytes in hepatitis $C$ virus infection. Hepatology. 2004; 40(5):1062-71. https://doi. org/10.1002/hep.20454 PMID: 15486925

9. Park JJ, Wong DK, Wahed AS, Lee WM, Feld JJ, Terrault N, et al. Hepatitis B Virus-Specific and Global T-Cell Dysfunction in Chronic Hepatitis B. Gastroenterology. 2016; 150(3):684-95.e5. https:// doi.org/10.1053/j.gastro.2015.11.050 PMID: 26684441

10. Butte MJ, Peñacruz V, Kim MJ, Freeman GJ, Sharpe AH. Interaction of human PD-L1 and B7-1. 2008; 45(13):3567-72. https://doi.org/10.1016/j.molimm.2008.05.014 PMID: 18585785

11. Protzer U, Maini MK, Knolle PA. Living in the liver: hepatic infections. Nature Reviews Immunology. 2012; 12(3):201-13. https://doi.org/10.1038/nri3169 PMID: 22362353

12. Kassel R, Cruise MW, lezzoni JC, Taylor NA, Hahn YS. Chronically Inflamed Livers Up-Regulate Expression of Inhibitory B7 Family Members. Hepatology. 2009; 50(5):1625-37. https://doi.org/10. 1002/hep.23173 PMID: 19739236 
13. Agina HA, Ehsan NA, Abd-Elaziz TA, Abd-Elfatah GA, Said EM, Sira MM. Hepatic expression of programmed death-1 (PD-1) and its ligand, PD-L1, in children with autoimmune hepatitis: relation to treatment response. Clinical and experimental hepatology. 2019; 5(3):256. https://doi.org/10.5114/ceh. 2019.87642 PMID: 31598564

14. Ren $\mathrm{H}$, Huang $\mathrm{Y}$. Effects of pegylated interferon- $\alpha$ based therapies on functional cure and the risk of hepatocellular carcinoma development in patients with chronic hepatitis $\mathrm{B}$. Journal of viral hepatitis. 2019; 26:5-31. https://doi.org/10.1111/jvh.13150 PMID: 31380584

15. Isorce N, Lucifora J, Zoulim F, Durantel D. Immune-modulators to combat hepatitis B virus infection: From IFN- $\alpha$ to novel investigational immunotherapeutic strategies. Antiviral research. 2015; 122:69-81. https://doi.org/10.1016/j.antiviral.2015.08.008 PMID: 26275801

16. Wang $\mathrm{H}$, Luo H, Wan X, Fu X, Mao Q, Xiang X, et al. TNF-a/IFN-y profile of HBV-specific CD4 T cells is associated with liver damage and viral clearance in chronic HBV infection. Journal of hepatology. 2019.

17. Lang J, Neumann-Haefelin C, Thimme R. Immunological cure of HBV infection. Hepatology international. 2019; 13(2):113-24. https://doi.org/10.1007/s12072-018-9912-8 PMID: 30600480

18. Benechet $A P$, lannacone $M$. Determinants of hepatic effector CD8+ T cell dynamics. Journal of hepatology. 2017; 66(1):228-33. https://doi.org/10.1016/j.jhep.2016.07.011 PMID: 27423427

19. Muhlbauer M. PD-L1 is induced in hepatocytes by viral infection and by interferon-alpha and-gamma and mediates T cell apoptosis. 2006; 45(4):520-8.

20. Zeng Z, Li L, Chen Y, Wei H, Sun R, Tian Z. Interferon-gamma facilitates hepatic antiviral T cell retention for the maintenance of liver-induced systemic tolerance. The Journal of experimental medicine. 2016; 213(6):1079-93. https://doi.org/10.1084/jem.20151218 PMID: 27139489

21. Li N, Wang J, Zhang N, Zhuang M, Zong Z, Zou J, et al. Cross-talk between TNF- $\alpha$ and IFN-y signaling in induction of B7-H1 expression in hepatocellular carcinoma cells. Cancer Immunology, Immunotherapy. 2018; 67(2):271-83. https://doi.org/10.1007/s00262-017-2086-8 PMID: 29090321

22. An J, Guo $P$, Shang $Y$, Zhong $Y$, Zhang $X, Y u$, et al. The "adaptive responses" of low concentrations of HBCD in L02 cells and the underlying molecular mechanisms. Chemosphere. 2016; 145:68-76. https://doi.org/10.1016/j.chemosphere.2015.11.071 PMID: 26688241

23. Li C, Wang Y, Wang S, Wu B, Hao J, Fan H, et al. Hepatitis B virus mRNA-mediated miR-122 inhibition upregulates PTTG1-binding protein, which promotes hepatocellular carcinoma tumor growth and cell invasion. Journal of virology. 2013; 87(4):2193-205. https://doi.org/10.1128/JVI.02831-12 PMID: 23221562

24. Zhao B, Wang Y, Zhang Y, Li Y, Zhang X, Xu Y, et al. TAT-mediated gp96 transduction to APCs enhances gp96-induced antiviral and antitumor T cell responses. Vaccine. 2013; 31(3):545-52. https:// doi.org/10.1016/j.vaccine.2012.11.011 PMID: 23149267

25. Wang S, Qiu L, Liu G, Li Y, Zhang X, Jin W, et al. Heat shock protein gp96 enhances humoral and T cell responses, decreases Treg frequency and potentiates the anti-HBV activity in BALB/c and transgenic mice. Vaccine. 2011; 29(37):6342-51. https://doi.org/10.1016/j.vaccine.2011.05.008 PMID: 21600951

26. Hou J, Li X, Li C, Sun L, Zhao Y, Zhao J, et al. Plasma membrane gp96 enhances invasion and metastatic potential of liver cancer via regulation of uPAR. Molecular oncology. 2015; 9(7):1312-23. https:// doi.org/10.1016/j.molonc.2015.03.004 PMID: 25841765

27. Fan H, Yan X, Zhang Y, Zhang X, Gao Y, Xu Y, et al. Increased expression of Gp96 by HBx-induced NF-kappaB activation feedback enhances hepatitis B virus production. PloS one. 2013; 8(6):e65588. https://doi.org/10.1371/journal.pone.0065588 PMID: 23776506

28. Marzec M, Zhang Q, Goradia A, Raghunath PN, Liu X, Paessler M, et al. Oncogenic kinase NPM/ALK induces through STAT3 expression of immunosuppressive protein CD274 (PD-L1, B7-H1). Proceedings of the National Academy of Sciences of the United States of America. 2008; 105(52):20852-7. https://doi.org/10.1073/pnas.0810958105 PMID: 19088198

29. Kondo A, Yamashita T, Tamura H, Zhao W, Tsuji T, Shimizu M, et al. Interferon-gamma and tumor necrosis factor-alpha induce an immunoinhibitory molecule, B7-H1, via nuclear factor-kappaB activation in blasts in myelodysplastic syndromes. Blood. 2010; 116(7):1124-31. https://doi.org/10.1182/ blood-2009-12-255125 PMID: 20472834

30. Garcia-Diaz A, Shin DS, Moreno BH, Saco J, Escuin-Ordinas H, Rodriguez GA, et al. Interferon Receptor Signaling Pathways Regulating PD-L1 and PD-L2 Expression. Cell Rep. 2017; 19(6):1189-201. https://doi.org/10.1016/j.celrep.2017.04.031 PMID: 28494868

31. Schroder K, Hertzog PJ, Ravasi T, Hume DA. Interferon-gamma: an overview of signals, mechanisms and functions. J Leukoc Biol. 2004; 75(2):163-89. https://doi.org/10.1189/jlb.0603252 PMID: 14525967

32. Aaronson DS, Horvath CM. A road map for those who don't know JAK-STAT. Science. 2002; 296 (5573):1653-5. https://doi.org/10.1126/science.1071545 PMID: 12040185 
33. Park EH, Koh SS, Srisuttee R, Cho IR, Min HJ, Jhun BH, et al. Expression of HBX, an oncoprotein of hepatitis B virus, blocks reoviral oncolysis of hepatocellular carcinoma cells. Cancer gene therapy. 2009; 16(5):453-61. https://doi.org/10.1038/cgt.2008.95 PMID: 19096445

34. Matsuda $Y$, Ichida $T$. Impact of hepatitis $B$ virus $X$ protein on the DNA damage response during hepatocarcinogenesis. Medical molecular morphology. 2009; 42(3):138-42. https://doi.org/10.1007/s00795009-0457-8 PMID: 19784739

35. Xia Y, Stadler D, Lucifora J, Reisinger F, Webb D, Hosel M, et al. Interferon-gamma and Tumor Necrosis Factor-alpha Produced by T Cells Reduce the HBV Persistence Form, cccDNA, Without Cytolysis. Gastroenterology. 2016; 150(1):194-205. https://doi.org/10.1053/j.gastro.2015.09.026 PMID: 26416327

36. Klenerman P, Hill A. T cells and viral persistence: lessons from diverse infections. Nature immunology. 2005; 6(9):873-9. https://doi.org/10.1038/ni1241 PMID: 16116467

37. van der Burg SH, Arens R, Melief CJ. Immunotherapy for persistent viral infections and associated disease. Trends in immunology. 2011; 32(3):97-103. https://doi.org/10.1016/j.it.2010.12.006 PMID: 21227751

38. Hakim MS, Rahmadika N, Jariah RO. Expressions of inhibitory checkpoint molecules in acute and chronic HBV and HCV infections: Implications for therapeutic monitoring and personalized therapy. Reviews in Medical Virology. 2019.

39. Weyand CM, Berry GJ, Goronzy JJ. The immunoinhibitory PD-1/PD-L1 pathway in inflammatory blood vessel disease. J Leukoc Biol. 2018; 103(3):565-75. https://doi.org/10.1189/jlb.3MA0717-283 PMID: 28848042

40. Boni C, Fisicaro P, Valdatta C, Amadei B, Di Vincenzo P, Giuberti T, et al. Characterization of hepatitis $B$ virus (HBV)-specific T-cell dysfunction in chronic HBV infection. Journal of virology. 2007; 81 (8):4215-25. https://doi.org/10.1128/JVI.02844-06 PMID: 17287266

41. Maier H, Isogawa M, Freeman GJ, Chisari FV. PD-1: PD-L1 interactions contribute to the functional suppression of virus-specific CD8+ T lymphocytes in the liver. The Journal of Immunology. 2007; 178 (5):2714-20. https://doi.org/10.4049/jimmunol.178.5.2714 PMID: 17312113

42. Frebel $\mathrm{H}$, Richter $\mathrm{K}$, Oxenius $\mathrm{A}$. How chronic viral infections impact on antigen-specific T-cell responses. European journal of immunology. 2010; 40(3):654-63. https://doi.org/10.1002/eji. 200940102 PMID: 20077405

43. Yong YK, Saeidi A, Tan HY, Rosmawati M, Enström PF, Batran RA, et al. Hyper-expression of PD-1 is associated with the levels of exhausted and dysfunctional phenotypes of circulating CD161++ TCR iVa7. 2+ mucosal-associated invariant T cells in chronic hepatitis B virus infection. Frontiers in immunology. 2018; 9:472. https://doi.org/10.3389/fimmu.2018.00472 PMID: 29616020

44. Liu J, Zhang E, Ma Z, Wu W, Kosinska A, Zhang X, et al. Enhancing virus-specific immunity in vivo by combining therapeutic vaccination and PD-L1 blockade in chronic hepadnaviral infection. PLoS pathogens. 2014; 10(1):e1003856. https://doi.org/10.1371/journal.ppat.1003856 PMID: 24391505

45. Bengsch B, Martin B, Thimme R. Restoration of HBV-specific CD8+ T cell function by PD-1 blockade in inactive carrier patients is linked to T cell differentiation. Journal of hepatology. $2014 ; 61(6): 1212-9$. https://doi.org/10.1016/j.jhep.2014.07.005 PMID: 25016223

46. Isogawa M, Chung J, Murata $Y$, Kakimi K, Chisari FV. CD40 activation rescues antiviral CD8+ T cells from PD-1-mediated exhaustion. PLoS pathogens. 2013; 9(7):e1003490. https://doi.org/10.1371/ journal.ppat.1003490 PMID: 23853599

47. Fisicaro $\mathrm{P}$, Valdatta $\mathrm{C}$, Massari M, Loggi E, Biasini E, Sacchelli L, et al. Antiviral intrahepatic T-cell responses can be restored by blocking programmed death-1 pathway in chronic hepatitis $\mathrm{B}$. Gastroenterology. 2010; 138(2):682-93. e4. https://doi.org/10.1053/j.gastro.2009.09.052 PMID: 19800335

48. Gane E, Verdon DJ, Brooks AE, Gaggar A, Nguyen AH, Subramanian GM, et al. Anti-PD-1 blockade with nivolumab with and without therapeutic vaccination for virally suppressed chronic hepatitis $\mathrm{B}$ : a pilot study. Journal of hepatology. 2019; 71(5):900-7. https://doi.org/10.1016/j.jhep.2019.06.028 PMID: 31306680

49. Jacobi FJ, Wild K, Smits M, Zoldan K, Csernalabics B, Flecken T, et al. OX40 stimulation and PD-L1 blockade synergistically augment $\mathrm{HBV}$-specific CD4 T cells in patients with $\mathrm{HBeAg}$-negative infection. Journal of hepatology. 2019; 70(6):1103-13. https://doi.org/10.1016/j.jhep.2019.02.016 PMID: 30826436

50. Dong H, Zhu G, Tamada K, Flies DB, van Deursen JM, Chen L. B7-H1 determines accumulation and deletion of intrahepatic CD8(+) T lymphocytes. Immunity. 2004; 20(3):327-36. https://doi.org/10.1016/ s1074-7613(04)00050-0 PMID: 15030776

51. Fletcher SP, Chin DJ, Cheng DT, Ravindran P, Bitter H, Gruenbaum L, et al. Identification of an intrahepatic transcriptional signature associated with self-limiting infection in the woodchuck model of hepatitis B. Hepatology (Baltimore, Md). 2013; 57(1):13-22. 
52. Penna A, Laccabue D, Libri I, Giuberti T, Schivazappa S, Alfieri A, et al. Peginterferon-alpha does not improve early peripheral blood HBV-specific T-cell responses in HBeAg-negative chronic hepatitis. Journal of hepatology. 2012; 56(6):1239-46. https://doi.org/10.1016/j.jhep.2011.12.032 PMID: 22326467

53. Hao J, Jin W, Li X, Wang S, Zhang X, Fan H, et al. Inhibition of alpha interferon (IFN-alpha)-induced microRNA-122 negatively affects the anti-hepatitis B virus efficiency of IFN-alpha. Journal of virology. 2013; 87(1):137-47. https://doi.org/10.1128/JVI.01710-12 PMID: 23055569

54. Snell LM, McGaha TL, Brooks DG. Type I Interferon in Chronic Virus Infection and Cancer. Trends in immunology. 2017; 38(8):542-57. https://doi.org/10.1016/j.it.2017.05.005 PMID: 28579323 